\title{
Corporate Governance, Risk Management and Compliance (GRC): The Crossroads Between Law Studies with International Relations and Diplomacy Studies Meeting Social Welfare
}

\author{
Niedja de Andrade e Silva Forte dos Santos \\ The Center for Administration and Public Policies at The Institute of Social and \\ Political Sciences, University of Lisbon/School of Law at the University of Coimbra, \\ Portugal \\ niedjasantos@icloud.com
}

\begin{abstract}
This paper aims to demonstrate how a tool adopted by businesses - the GRC Corporate Governance, Risk Management, and Compliance - links two academic disciplines, namely Law Studies and International Relations Studies. The GRC is a promising instrument for ensuring companies are socially responsible, contributing to social welfare. The lack of studies demonstrating the link between the two academic disciplines by a concrete resource, such as the GRC, justifies the scientific relevance of this paper. The study is also pivotal from the social perspective, as it may contribute to future studies on the role of corporations in the promotion and management of social welfare. The main argument is that the GRC is located at the crossroads of Corporate Law Studies and Diplomacy Studies. The paper explores the conceptual frameworks of corporate law studies, international relations, and diplomacy studies. As well, it operationalizes the notion of GRC Corporate Governance, Risk Management, and Compliance by detailing its components. Then, there is an analysis of the GRC at the crossroads between the two disciplines. The main find of this research is that corporate diplomacy is the bridge that links corporate law studies and diplomacy studies. Future research may focus on frameworks to favor such kind of analysis. Comparative research is also welcomed.
\end{abstract}

Keywords: GRC, Law studies, International relations studies, Social welfare, Corporate diplomacy

\section{Introduction}

At the current age, corporations are equally or even more powerful than states. The U.S. retailer Walmart reached US\$ 559 billion in revenue in 2020 [1], which means more than the Swedish or Belgian GDP, respectively US\$ 538 billion and US\$ 515 billion in the same period [2]. This scenario, together with the risk society described by Beck [3], called corporations to improve social welfare together with states [4]. In general, companies participate in this topic through their Corporate Social Responsibility (CSR) programs, which are mainly focused on local communities. However, when it comes to multinational corporations, participation in the promotion of social welfare also includes actions at the international level linked to ethical and humanitarian values. For instance, companies can join the voluntary and transnational initiative

Article history:

Received (April 15, 2021), Review Result (May 16, 2021), Accepted (August 15, 2021) 
"United Nations Global Compact," which supports, at the international level, companies working on the sustainable development goal 16 of the 2030 Agenda. The UN Global Compact (UNGC) inspires transformational governance, "with guidance on strengthening business culture, ethics, and performance." [5]. This is an example of corporate diplomacy.

The UNGC is mostly grounded on soft law instruments. Soft law "consists of rules which are not legally binding, but which still intend to produce changes in behavior from those it regulates" [6]. From the academic perspective, soft law can be studied as a non-binding legal provision, as well as a result of performance in foreign environments. From a corporate practitioner's perspective, the UNGC can be taken as an act of international cooperation; thus, linked to diplomacy. The adhesion to the UNGC involves corporate law, as well as international relations and diplomacy perspectives. Specifically, it involves contributions of corporations to the social welfare by applying principles related to human rights protection, recognition of the employees' right to collective bargaining and freedom of association, fights against forced and child labor, elimination of discrimination, environment protection, and corruption abolishment [7]. Nevertheless, those are voluntary commitments that are not encompassed by national mandatory provisions. The effective benefit for social welfare depends on the spontaneous compliance by companies with international principles.

The Corporate Governance, Risk Management, and Compliance, or simply GRC, is a novel management tool adopted by companies to ensure the alignment with legally binding and nonbinding provisions. Especially in the case of multinational companies or corporations affiliated with international initiatives like the UNGC, the GRC has the potential to safeguard corporate actions towards social welfare. However, as a relatively new instrument, currently embraced preferably by large corporations, little is known about the framing of the GRC.

Therefore, this research aims to evidence how the GRC links two academic disciplines, namely Law Studies and International Relations Studies. The main argument is that corporate diplomacy links the two scientific fields. It is noteworthy that this paper does not intend to exhaust the subject, it outlines primary and general lines on the theme, to instigate deeper future research. Hence, this is rather a provocative and reflexive essay than an exploratory or an intended convincing paper. To achieve that aim, the next sections explore the conceptual frameworks of corporate law studies, international relations, and diplomacy studies. As well, it operationalizes the notion of GRC Corporate Governance, Risk Management, and Compliance by detailing its components. Then, there is an analysis of the GRC at the crossroads between the two disciplines. The final section presents the conclusion and indicates paths for future research and developments.

\section{Corporate law studies}

Corporate Law Studies (CLS) is an academic subdiscipline that is part of Law Studies. Sometimes called business law or company law studies, CLS is a body within private law dedicated to the legal practice of corporations, from their creation until death, encompassing governance, funding, and related aspects. Since the notion of a corporation may vary among countries, Wells identified five legal characteristics shared by businesses across jurisdictions: (1) legal personality, (2) limited liability, (3) transferable shares, (4) board structure for management, and (5) investor ownership [8]. Then, the author considers corporate law the discipline which focuses on those components. Hence, corporate governance is a subject within corporate law studies and interests the topic of this essay.

The renowned Portuguese Corporate Law Professor Coutinho de Abreu states that corporate governance is the collection of a wide range of binding and non-binding rules including national 
laws, statutory norms, judicial provisions, and ethical premises that relate to the management, control, and supervision of corporations [9]. It is noteworthy that after studying corporate governance through the legal comparative method in more than twenty countries, Hopt warned that since corporate governance is a new term in most countries, it does not feature a common definition [10]. Therefore, the German Professor and Former Director of the Max Planck Institute for Comparative and International Private Law Hamburg concluded that in a global perspective, a broad definition including direction and control of companies as core elements better explain corporate governance. The definition provided by the Cadbury Report meets this requirement stating that corporate governance is "the system by which companies are directed and controlled" [11].

Recently, the stakeholder capitalism approach emerged in the corporate governance realm as a theoretical trend that strengthens the role of corporate boards in overseeing and guiding management focused on the long-term, involving objectives of a wide range of stakeholders while creating value for companies [12]. By doing this, companies expand their lens for developing and communicating corporate governance activities that both enhance value for shareholders and address the needs of the civil society, namely their customers, local communities, employees, regulators, among others [13], with direct outcomes to the social welfare. Currently, companies may increase their value and strengthen their brand when reporting non-financial information.

Hence, this research defines corporate governance law studies as the field within law studies which focus on the role of the board in the direction and control over companies, including not only legal provisions and shareholders' interests but also non-binding rules and stakeholders' needs. In this token, the activity of corporate boards of implementing soft law concepts and social welfare guidelines like the UNGC is within the scope of corporate governance and corporate law studies.

\section{International relations and diplomacy studies}

International relations are a discipline born from social sciences and political sciences dedicated to the study of a wide range of topics related to the international and global dimension, like the diplomatic, strategic, and geopolitical relations of states, war, and peace, conflict, and cooperation, globalization, issues related to migrants and refugees, international communication, transnational economy, among others. Those topics are usually referred to as low and high political issues. The delimitation of the scope of international relations evolves with the evolution of society. For instance, cyber diplomacy, which refers to the diplomatic interactions in cyberspace is a very new theme of international relations [14]. In this sense, Brown and Ainley state that "there is a continual interplay between the 'real world' and the world of knowledge" [15].

Specifically, the diplomacy and public diplomacy studies interest the aims of this paper. In this regard, it is essential to differentiate traditional diplomacy, public diplomacy, and new public diplomacy. Snow claims that traditional diplomacy comprises government-togovernment $(\mathrm{G} 2 \mathrm{G})$ relations, while public diplomacy is the dialogue between governments and global publics (G2P), aiming to engage them with foreign policy objectives [16]. Melissen adds that traditional diplomacy also involves intergovernmental organizations, while public diplomacy involves a wide range of non-state actors in a multilevel, diverse and collaborative environment between nonsymmetrical actors [17].

Crosswise public diplomacy, international influence is everyone's business. This means that diplomats linked to states are not the only ones to project the country's overall international 
reputation and influence. In this regard, multinational corporations can be influential diplomatic actors in the framework of corporate or business diplomacy. Ruël states that business or corporate diplomacy is the diplomat-like activity conducted by companies in collaboration with governments or other types of businesses' stakeholders [18]. Hence, as diplomatic actors, companies develop programs, at the local level, linked to previous international commitments related to social welfare.

\section{Corporate governance, Risk management, and Compliance (GRC)}

The corporate tool known by the acronym GRC, means corporate governance, risk management, and compliance. It is a resource integrated by skills, tools, and capabilities that enable a company to act with integrity and address uncertainty while promoting reliability in goals achievement. Thus, as an integrity resource, the GRC impacts social welfare. To understand accordingly the GRC is important to analyze each one of its components: risk and risk management, compliance, and corporate governance.

\subsection{Risk and risk management}

Some claim that the idea of risk was born in 1654 with the theory of probabilities. In this token, the renaissance rational process for facing risks replaced the oracles [19]. Others argue that the notion of risk had been born at the end of the Middle Ages, related to navigation and trade in the East [20]. Regardless of the birth in statistics or securities, the study of risk developed predominantly in the field of finance and economics [21]. Contemporaneously, it has also been analyzed under different perspectives, such as climate change, security, civil protection, engineering, psychology, sociology, philosophy, among others. Markedly, studies on corporate governance began to incorporate risk, especially after the 2007/2008 global financial crisis. Chavas defines risk as "any situation where some events are not known with certainty" [23]. In general, concepts and notions of risk are usually linked to uncertainty and the future. In the corporate dimension, the risk is the chance or hypothesis of occurrence of a future and uncertain event in the market, credit, liquidity, strategy, reputation, and operations dimensions, with potential for negative impact on the expected results of the company.

Then, in corporations, risk management is usually linked to audit, internal controls, and compliance. In the U.S., risk management emerged as a function related to management skills [24]. In Europe, it was born linked to the supervisory body of financial companies. In the scope of corporate governance [25], Murphy states risk management is monitoring unwanted events, involving the identification of risks that one intends to accept - 'risk appetite' [26]. With another perspective, Miller defines risk as actions of an organization aimed at dealing with future uncertainties [27]. Thus, risk management within the scope of corporations may be described as the often-discretionary process that involves mapping, analysis, decision-making, and contingency of risks related to overall business activities to ensure the achievement of corporate goals.

\subsection{Compliance}

The compliance practice emerged in the US together with the Foreign Corrupt Practices Act (FCPA) in 1977 [28]. In 1996, the Chancery Court of Delaware ruled that, by a duty of care, corporate directors would be responsible for overseeing compliance programs, being responsible for failures in implementation, monitoring, or reporting [29]. Recently, another American judicial decision reinforced the recognition of the discretion in the implementation 
of compliance programs by corporate directors in good faith, however, they must demonstrate that they have put in place a reasonable system of risks and compliance [30]. In the European Union, compliance is mandatory for financial companies with similar responsibilities of directors [31].

As Miller states, compliance is composed of procedures of controlling and monitoring enforcement within organizations. On the other hand, Hauschka involves stakeholders in the definition of compliance, declaring that compliance aims to ensure commitment with legal provisions, regulatory standards, and the fulfillment of other essential requirements of the stakeholders [27].

\subsection{Corporate governance}

In the early 2000s, accounting scandals gave rise to the Sarbanes-Oxley Act of 2002 in the US, which consolidated pillars of corporate governance. At the beginning of the 21 st century, several self-regulation codes of corporate governance in the comply or explain model appeared. Then, the subprime crisis in 2007/2008 boosted risk management linked to corporate governance, especially in the financial and banking sectors. [32] In this context, the GRC started to be analyzed in the context of corporate governance. Currently, the crisis arising from the COVID-19 pandemic will certainly leverage the GRC trend in the legal-corporate perspective of corporate governance. This paper adopts Abreu's definition for corporate governance: "complex of rules (legal, statutory, jurisprudential, deontological), instruments and issues relating to the administration and the control or supervision) of corporations" [33].

\subsection{GRC - Governance, Risk management, and Compliance}

Like corporate governance, the GRC - Governance, Risk Management, and Compliance were not born in the legal field [34]. Currently, the tool is predominantly used in US corporations, being less known in other countries. Miller warns that activist shareholders, institutional investors, and policymakers increasingly perceive the GRC as a way to improve business ethics, as well as to prevent violations of norms and rules, as well as unsafe or illegal practices [27]. Additionally, it is a useful resource to monitor the compliance of soft law to which corporations are internationally committed. This scenario is likely to signal the relevance of the GRC in the life of corporations.

Miller offers a unified notion for GRC from the perspective of corporate law, which highlights its importance as a corporate tool (which he names "system"). The author states that the GRC is the collection of rules, guidelines, procedures, and best practices that, individually and collectively, intend to ensure that organizations are managed in such a way that enhances social welfare [27].

All in all, this paper defines the GRC as the discretionary tool constituted of integrated measures to provide risk management, monitoring, control, compliance, and corporate governance implemented by companies to get multidimensional outcomes, namely at the internal and external levels. Inside the corporations, GRC supports good management and governance, for instance, ensuring the rights of employees and preventing corruption. As well, the GRC impacts the external dimension, as it ensures the socially responsible role of companies in civil society. Also, the GRC monitors compliance with international conventions and treaties, such as the UNGC. Therefore, the GRC is a relevant resource for companies' performance and social welfare at the national and international levels, especially when adopted by multinational companies. All in all, it ensures the overall effectiveness of an entity towards a civil and global society. 


\section{Corporate diplomacy: The GRC at the crossroads}

As stated by Westermann-Behaylo, Rehbein, and Fort, corporate diplomacy "includes the political role those multinational enterprises play in addressing social issues and governance gaps affecting less developed and potentially conflict-prone host countries where they are" [35]. Authors state that, especially in the case of multinational companies, corporate diplomacy can accommodate policies, besides incorporating short- and long-term plans, strategies, and measures to reduce political tensions in a community. From the perspective of corporate governance, the primary goal of companies is usually self-interest (most of the time, revenue), which also is usually shareholders' first interest. From the corporate diplomacy perspective, corporations develop collaborative efforts to fulfill governance needs, especially related to their role in the communities where they are inserted.

In reality, the body of knowledge around corporate diplomacy is sparse and predominantly integrated by studies in the field of political corporate social responsibility, international public relations, and public diplomacy [36]. The corporate law approach is underexplored. Nevertheless, the corporate law and the legal corporate governance perspectives should add synergy to efforts in this area. Specifically, some of the actions of corporate diplomacy imply a commitment to international guidelines and non-binding treaties and conventions. Thus, the corporate law point of view would support effective impacts and outcomes to social welfare.

In this regard, as an instrument that focuses on the identification of legal, normative, and other risks, foreseeing how they can be managed through corporate governance practices, as well as identifying rules, norms, and binding and non-binding legal provisions that should be complied, the GRC is a promising tool to be used not only in the corporate governance context but also as a resource for making international cooperation effective. Then, this paper sets up the GRC at the crossroads of both academic disciplines: corporate law studies and international relations and diplomacy studies. In reality, the GRC can be interpreted as a corporate resource that also matters for society, both at the national and international levels. Therefore, undoubtedly, the proper use and effective outcomes of the GRC should benefit from more research linking the two disciplines: law and international relations.

\section{Conclusion}

In the contemporary world, corporations are equally or more important than states; thus, they are constantly taken as responsible for promoting social welfare together with states. From the international perspective, the action on social welfare might involve especially the deep commitment to ethical and humanitarian values such as avoidance of child labor, human rights of employees, environment protection, and the fight against corruption expressed in global treaties or conventions grounded on soft law aligning companies in the flow of global social welfare.

When a company needs to monitor compliance with binding and non-binding laws, the corporate governance, which is the system of control and management of companies, is called from the corporate law studies. Those corporate commitments towards social welfare should be monitored by corporate governance. Markedly, the stakeholder capitalism approach set up corporate outcomes to the social welfare at the heart of the corporate governance and interests of a company. In the meantime, the international performance of companies, namely interactions in the scope of international organizations, adherence to international treaties and guidelines, as well as actions related to that, for instance, the development of the United National Global Compact premises, companies active in the terrain of public diplomacy. 
Specifically, they touch corporate diplomacy. To sum up, actions of corporate diplomacy link corporate law studies with international relations studies when companies work towards social welfare linked to international standards.

GRC as a way to improve business ethics, as well as to prevent violations of norms and rules, as well as unsafe or illegal practices, alongside being a useful resource to monitor the compliance of soft law to which corporations are internationally committed. In other words, as a resource that integrates measures to provide risk management, compliance with rules, and corporate governance with multi-dimensional outcomes, at the internal and external levels, the GRC is promising for ensuring the overall effectiveness of an entity towards civil and global society in actions and programs involving corporate diplomacy. Thus, the GRC is at the crossroads of both disciplines, law, and international relations. However, the field requires more research to fully understand how the GRC is exercised within companies and which users can effectively be done in the external dimension, including national and international perspectives. In the last case, future research on the role of GRC for ensuring principles of the United National Global Compact may be very useful.

In conclusion, the topic of GRC is promising. There is a path opened for further developments by scholars, practitioners, and corporate directors. This author suggests that it will become a more institutionalized resource. As highlighted in the introduction, this paper intended to be only a provocative essay, not a full roadmap on the pivotal role of the GRC in the crossroads of corporate law and diplomacy studies. Therefore, more academic and practitioner understanding are required to define responsibilities, overcome risks and potentialize outcomes. The attention of scholars should focus on building frameworks of corporate diplomacy which link corporate law studies and diplomacy studies. This would favor developments from the empirical perspective as well as comparative research.

\section{References}

[1] S. E. Kohan, "Walmart revenue hits $\$ 559$ billion for the fiscal year 2020," Forbes, February 18, (2021)

[2] World Bank, "GDP (current US\$)," The World Bank Data, Washington, (2021)

[3] U. Beck, "Risikogesellschaft: Auf dem Weg in eine andere Moderne," Suhrkamp, Frankfurt, (1986)

[4] S. Sonenshein, "How corporations overcome issue illegitimacy and issue equivocality to address social welfare: The role of the social change agent," Academy of Management Review, vol.41, no.2, pp.349-366, (2016)

[5] UN Global Compact, "UN global compact launches SDG 16 business framework to inspire transformational governance," UN Global Compact Press Release, 1 Jun. (2021)

[6] R. Ghafele and A. Mercer, "Not starting in sixth gear: An assessment of the U.N. global compact's use of soft law as a global governance structure for corporate social responsibility," Journal of International Law and Policy, vol.17, no.1, pp. 41-62, (2010)

[7] United Nations Global Compact, "The ten principles of the UN global compact," United Nations, New York, (2021)

[8] H. Wells, Introduction, in H. Wells (Ed.), "The research handbook on the history of corporate and company law," Elgar, Cheltenham, (2018)

[9] J. M. C. de Abreu, "Governação das sociedades," 2nd ed., Almedina, Coimbra, (2010)

[10] K. J. Hopt, "Comparative corporate governance: The state of the art and international regulation," in A. M. Fleckner and K. J. Hopt, Comparative Corporate Governance: a functional and international analysis, Cambridge University Press, Cambridge, (2013)

[11] A. Cadbury, "Report of the committee on the financial aspects of corporate governance," Gee, London, (1992)

[12] S. Klemash, J. C. Smith, and R. Doyle, "Stakeholder capitalism for long-term value creation," Harvard Law School Forum on Corporate Governance, Cambridge (2019) 
Corporate Governance, Risk Management and Compliance (GRC): The Crossroads Between Law Studies with International Relations and Diplomacy Studies Meeting Social Welfare

[13] Ibid.

[14] S. Riordan, "Cyberdiplomacy: Managing security and governance online," Polity, Cambridge, (2019)

[15] C. Brown and K. Ainley, "Understanding international relations," 3rd ed., Palgrave, Hampshire, (2005)

[16] N. Snow, "Rethinking public diplomacy," in N. Snow \& P. M. Taylor (Eds.), Routledge Handbook of Public Diplomacy, Routledge, New York, (2009)

[17] J. Melissen, "The new public diplomacy: Between theory and practice," in J. Melissen (Ed.), The new public diplomacy: Soft power in international relations, Palgrave, London, (2005)

[18] H. Ruël, "Multinational corporations as diplomatic actors: An exploration of the concept of business diplomacy," Diplomatica, vol.17, no.1, pp.1-12, (2020)

[19] P. L. Bernstein, "Desafio aos deuses: A fascinante história do risco,” Rio de Janeiro: Elsevier, pp.2-8, (1997)

[20] N. Luhmann, "Risk: Sociological theory,” de Gruyter, Berlin, (1993)

[21] G. G. Szpiro, "Risk, choice, and uncertainty: Three centuries of economic decision-making," Columbia University Press, New York, (2020)

[22] C. Amatucci, "Vigilanza, gestione dei rischi e responsabilità degli amministratori di società quotate," Rivista Delle Società," anno 60, no.2-3, pp.350-373, (2015)

[23] J. -P. Chavas, "Risk analysis in theory and practice," Elsevier, San Diego, (2004)

[24] R. R. Moeller, "COSO enterprise risk management: Establishing effective governance, risk and compliance processes," 2nd ed., Wiley, Hoboken, (2011)

[25] P. Maia, "O administrador independente e a gestão de risco," Proceedings of the Colóquio Gestão de Risco, Controlo Interno e Auditoria nas Sociedades Comerciais FDUC, Coimbra, Portugal, November 18, (2019)

[26] D. Murphy, "Understanding risk: The theory and practice of financial risk management," Chapman \& Hall, London, (2007)

[27] G. P. Miller, "The law of governance, risk management, and compliance," Wolters Kluwer Law \& Business, New York, (2014)

[28] M. Josephson, "History of the integrity, ethics and compliance movement: A cautionary tale for CEOs and corporate directors," Ethikos: The Journal of Practical Business Ethics, vol.28, no.1, pp.13-16, (2014)

[29] In Re Caremark International Inc. Derivative Litigation, 698 A.2d 959, Del. Ch. (1996)

[30] Marchand v. Barnhill, 212 A.3d 805, Del., (2019)

[31] Basel Committee on Banking Supervision, "Compliance and the compliance function in banks," Bank for International Settlements, Basel, (2005)

[32] T. M. N. Sá, “A influência do governo das sociedades nas alterações do risco na sequência da crise financeira global," Cadernos do Mercado de Valores Mobiliários, vol.50, pp.1-2,7, (2015)

[33] J. M. C. de Abreu, “Governação das sociedades,” 2nd ed., Almedina, Coimbra, (2010)

[34] P. O. Mülbert and A. Wilhelm, "Risikomanagement und compliance im finanzmarktrecht - entwicklung der aufsichtsrechtlichen anforderungen," ZHR, vol.178, no.5, pp.502-546, (2014)

[35] M. K. Westermann-Behaylo, K. Rehbein, and T. Fort, "Enhancing the concept of corporate diplomacy: Encompassing political corporate social responsibility, international relations, and peace through commerce," Academy of Management Perspectives, vol.29, no.4, pp.387-404, (2015)

[36] D. Ingenhoff and S. Marschlich, "Corporate diplomacy and political CSR: Similarities, differences, and theoretical implications," Public Relations Review, vol.45, no.2, pp.348-371, (2019) 


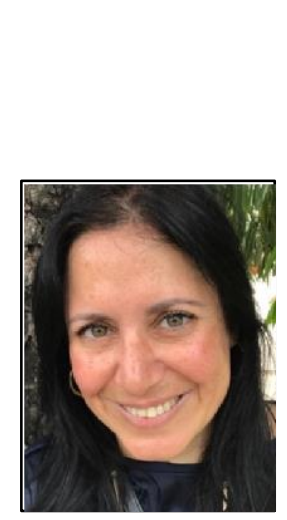

\section{Author}

\section{Niedja de Andrade e Silva Forte dos Santos}

Researcher at the Center for Administration and Public Policies at Institute of Social and Political Sciences, University of Lisbon (CAPPISCSP/FCT). Public diplomacy practitioner at the UNESCO Creative Cities Network (UCCN) and experienced in corporate diplomacy in the Brazilian private sector. Former Deputy Secretary of Economic Development and Innovation and Director of innovation at Santos, Brazil. Ms. Santos holds a Law degree and an MSC in Law. Keynote speaker in conferences in Asia and Europe and author of academic papers published in indexed journals. Her main interests are international relations, public diplomacy, corporate diplomacy, city diplomacy, corporate governance, and GRC. 
Corporate Governance, Risk Management and Compliance (GRC): The Crossroads Between Law Studies with International Relations and Diplomacy Studies Meeting Social Welfare

This page is empty by intention. 